\title{
Image of the family in European and Russian cultural tradition
}

\author{
Angelina Dmitriychuk ${ }^{1, *}$, Tamara Lipich ${ }^{2}$, Igor Lyashenko ${ }^{3}$, and Eduard Lykov \\ ${ }^{1}$ Department of Russian Language and Business Communication, Belgorod University of Cooperation, \\ Economics and Law, Belgorod, 308023, Russia \\ ${ }^{2}$ Department of Theology and Philosophy, Belgorod State National Research University, Belgorod, \\ 308000, Russia \\ ${ }^{3}$ Department of English Philology and Cross-Cultural Communication, Belgorod State National \\ Research University, Belgorod, 308007, Russia
}

\begin{abstract}
The article covers some issues regarding the development of the image of the family in European and Russian cultures. The family is considered as a biological, psychological and social system, establishing certain realities that perform various functions. The study reveals that in Western European countries rational behavior regulators dominate in family and marriage relations, while in Russian families spiritual and moral values traditionally act as behavior regulators. The authors identify the main trends and factors in the transformation of the image of the family in Europe and Russia: a decline in births, a change in family size, an increase in the openness of the sexual sphere, and tolerance of premarital sex. Overcoming such tendencies is seen in the revival and strengthening of the traditional family on a new basis, taking into account the spiritual component, in the preservation and enhancement of family values. The authors conclude that the revival of the institution of the traditional family helps to strengthen not only the family, but also society.
\end{abstract}

\section{Introduction}

The family is a bearer of spiritual and cultural traditions, which are reflected in the existence of a civilized society. The state of the family reflects the state of the whole society. In a family, a person comprehends the basics of being. Thus, it is possible to preserve both the whole society and mankind through the preservation and revival of the institution of the family.

In recent years, we can observe an increased interest in studying family problems in the national philosophical and cultural tradition, which is associated with modifications of both modern society and the very image of the family, as well as transformations in family and marriage relations. Therefore, this topic takes on special significance.

There are several points of view on the processes of family transformation in modern Russian society: S.A. Sorokin, A.I. Antonov, T.A. Gurko, Yu.A. Gasparyan and other authors argue that the failure to fulfill the basic family functions of having and brining up children

\footnotetext{
*Corresponding author: angelina.dm@mail.ru
} 
contributes to the crisis of the family institution; S.I. Golod, V.B. Golofast, A.A. Kletsin view changes in family functioning as an evolutionary factor.

In their studies, A.I. Antonov, P. Sorokin, A.G. Kharcheva, S.I. Golod, T. Parsons, give special attention to the structure and functions of the family. We noted that "the existence of a family as a system is possible as long as its functions and structure are preserved. Family transformation implies a change in both the structure and the basic family functions, which leads to a crisis that is characterized by the destruction of the traditional structure as a whole" [1].

One can better understand changes in the image of the family in society through researches of various works dedicated to the study of various issues of gender and family in the context of the culture of Europe and Russia, which helps to identify the specifics of the family at different stages of development, take a new look at the relationship between the traditional and innovative in the ideas of the family in the aspect of the current socio-cultural situation.

The article is aimed at revealing some philosophical and anthropological features and modern transformations of the image of the family in European and Russian cultural tradition.

The main objectives of the study are:

1) to establish the specific features of the formation of the image of the family in the European and Russian culture;

2) to analyze the main features of the formation of the image of the family in the European and Russian cultural traditions of the XIX - XX centuries;

3 ) to identify the main trends and factors of transformation of the image of the family in Europe and in Russia in the XIX - XXI centuries.

\section{Formation of the image of the family in the cultural traditions of Europe and Russia}

The study of the image of the family, its philosophical and cultural understanding raises certain interest, since this subject has an undoubted ideological significance. Comprehension of the role of the family in the life of society acquires high relevance in the middle of the XIX century. The interest in the "family issue" seems to be associated with the activation of women's struggle for equality with men both in socio-political and economic rights, which is reflected in family and marriage relations. In the Western European cultural tradition, the image of the family had ambivalent assessments: it was endowed with the highest significance, reduced to the function of procreation. In contrast, in the Russian cultural tradition, the image of the family acquires a special status associated primarily with the problem of understanding the essence of the family, going from mythology to religion and philosophy, which is connected, in our opinion, with the realistic and idealistic theory of the origin of family and marriage (according to S. V. Troitsky).

In his study "Christian philosophy of marriage", S.V. Troitsky calls the family the foundation of marriage and historically identifies two theories of the origin of the family and marriage "cutting across its entire course. One can be called realistic, the other - idealistic. The first sees the meaning of marriage in reproduction, in offsprings" [2].

The realistic theory of the origin of the family and marriage was especially popular in the West among Latin theologists. That is why, in our opinion, in Western countries, the family is primarily examined as a biological, psychological and social system that establishes corresponding realities that perform various functions.

The family is investigated from a biological point of view by T. Parsons, E. Wilson, C. McDonald, and other authors. T. Parsons undertook a sex-role approach, based on the implicit recognition of biological determinism of gender roles, indicating the representation of congenital masculine and feminine principles. He singles out instrumental and expressive 
functions associated with certain norms of behavior: instrumental functions require such qualities as imperiousness, decisiveness; expressive functions require softness, ability to compromise [3]. Therefore, the man is supposed to perform an instrumental function, the woman - an expressive one. According to T. Parsons, the redistribution of gender roles in the family - the desire of women to play the role of breadwinner - contributes to the transformation of family and marriage relations.

Modern philosopher V.M. Rozin emphasizes that "sexual desire, included in love and human relationships, is as much a biological process as a mental one" [4].

E. Bern, W. Thomas, C. Cooley, W. James, J. Piaget and Z. Freud analyze family and marriage relations primarily within the framework of the psychological system. Z. Freud developed the doctrine of sexuality. The author determines sexual love as "the relationship between a man and a woman who created a family on the basis of their sexual needs" [5].

From the point of view of the sphere of social cognition, the family is represented in the studies of P. Sorokin, E. Burgess, and other authors in the entire spectrum of ethical, spiritual, moral, and aesthetic values. Studying family problems, P. Sorokin calls cyclical changes, integration and disintegration as the main explanatory principles. "Sorokin now sees a way out of the crisis in a return to its traditional forms, but at a different turn in history. The means should be the "'moral reconstruction' of mankind, filling the old forms with relatively 'new' content. The best illustration of this idea is the aphorism "Family is a small church". It is such a union that will help mankind save itself from the general crisis" [6]. We share the point of view of P. Sorokin and believe that the revival of the institution of the traditional family (on a new basis) contributes to strengthening not only the family, but also society.

As T.I. Lipich and A.Yu. Dmitriychuk state: "If we take a look at family upbringing and family relationships in Russia, then we can conclude that they are deeply rooted in the spiritual and moral traditions of the country," [7]. Such an approach to family research is possible within the framework of the idealistic theory of the origin of family and marriage, which became widespread in Russia, in which the essence of the family is, first and foremost, spiritual and moral unity and improvement of spouses, striving for integrity.

In our opinion, in Western European countries, rational behavioral regulators dominate (both in society and in the family), values of individualization and liberalization prevail, while in the Russian sociocultural space, spiritual and moral values (as a regulator of behavior in society and family) dominate.

\section{The main trends and factors of transformation of the image of the family in Europe and Russia}

Analyzing the evolutionary changes of the monogamous family, S.I. Golod comes to the following conclusions: since the second half of the XIX century, under the influence of a number of factors, a partnership (democratic) type of family has been formed in Europe (later in Russia). "On the one hand, more or less equal relations between husband and wife led to the emergence of a stable dependence of expressive satisfaction with marriage, and, on the other, to the realization that sexuality practiced within the boundaries of marriage is not limited to childbirth. All this leads the spouses to think about the need to plan the time of birth of their children and their number" [8]. As a consequence, there appears a family transformation factor: separation of the sexual function from the reproductive function (the desire for sensual pleasure), which contributes to the openness of the sexual sphere.

Cybersex is gaining momentum in the Internet. Today, young people are invited to play the "Virtual Family". The task of virtual spouses includes the replacement of shortcomings or the absence of real spouses.

After analyzing the "sexual reform" in our country of the Soviet period, N.L. Pushkareva, Z.Z. Mukhina, and N.A. Mitsyuk note the "vitality of tradition and patriarchal standards" [9]. 
M.A. Kashina, L.A. Vasilenko believe that "the traditional roles of men and women are becoming more prominent in the public consciousness" [10]. We are convinced that it is the return to the Orthodox family traditions and spiritual sources that is able to stop the crisis of the traditional family. The main trends in the transformational processes of the late modernity image of the family are associated with the loss of traditional principles of gender identity by men and women.

Decline in childbirth is an important factor in the transformation of the family. In our opinion, the reasons contributing to the decline in childbirth include, on the one hand, the professional employment of women, their desire for career growth, and, on the other, the economic function of the family. We share the point of view of P. Sorokin, who points out: "Both the reason for the weakening of the family, and, at the same time, the sign of its breakdown is the fact of a decrease in childbearing in marriage" [11].

The economic situation and political destabilization are important factors in the transformation of family and marriage relations, as noted by G.G. Sillaste: "The change in the institution of property and political destabilization, which became the progenitors of the Russian transition economy, led to transitions in the social, spiritual, and even family and household spheres" [12].

The spread of education has contributed to the socio-political and social activity of women. Their participation in the scientific, social and cultural spheres has a negative effect on the family, as the woman spends less time at home and gives less time to family responsibilities (child care, housekeeping), which leads to transformations of the traditional image of the family.

In his essay "The divertissement of feminism", B. Smorodin states: "One should note that the establishment of equality between a man and a woman has fundamentally changed society, and, above all, it has affected family and marriage. Not long ago, marriage seemed an unshakable institution established for the joint living of one man and one woman for the birth and upbringing of children ... Now it has been pushed aside by cohabitation in different forms: with or without joint household, a marriage between three-four people, same-sex marriage..." [13].

Gradually, there is a departure from the traditional patriarchal family structure, in which the man was usually assigned the role of a "breadwinner", a "wage earner"; the woman was usually engaged in raising children and running a household.

\section{Conclusion}

The study allows us to draw conclusions and highlight the factors influencing the transformation processes of the axiological sphere of the family: a) historical, cultural and ideological conditions; b) the separation of sexual function from reproductive (the desire to obtain sensual pleasure); c) the economic situation; d) decline in childbirth; e) increased openness of the sexual sphere.

Thus, the following trends have been noted in recent decades in Western countries (to a greater extent) and in Russia (to a lesser extent): a transition from the patriarchal model of family relations to different forms and types of families; growing tolerance of premarital sex; increased openness of the sexual sphere; an increase in the number of unregistered unions; tendency to late marriages; family diminution; the predominance of families with one child; an increase in the number of children born out of wedlock; voluntary childlessness.

Overcoming these trends is seen in the revival and strengthening of the family. Strengthening the family institution is an effective condition for the development of both European and Russian society. Fundamental values include faith, loyalty, chastity, femininity, masculinity, caring, humility, mutual understanding, love, fatherhood, motherhood, parenthood, and honoring parents. All these values contribute to the revival of 
the institution of the family. A return to the traditional family on a new basis, taking into account the spiritual component, is able to preserve and revive the institution of the family in Russia and in Europe.

\section{References}

1. A.Yu. Dmitriychuk, On the issue of family transformation in modern Russian society, Sc. Bull. of BelSU. Ser. "Phil. Soc. Law" Belgorod, 333, (2018).

2. S.V. Troitsky, Christian philosophy of marriage. Information on https://azbyka.ru/otechnik/Sergej_Troickij/hristianskaja-filosofija-braka/1 (Accessed 18 April 2019) (1997).

3. T. Parsons, The system of modern societies (Aspect-Press, Moscow, 1998).

4. V.M. Rozin, Love and sexuality in culture, family and views on sex education (Logos, High School, Moscow, 1999).

5. Z. Freud, Dissatisfaction with culture (Znanie, Moscow, 1989).

6. I.A. Golosenko, Sociologi of Pitirim Sorokin, The history of bourgeois sociology in the first half of the $20^{\text {th }}$ century (Nauka, Moscow, 1979).

7. T.I. Lipich, A.Yu. Dmitriychuk, Family in philosophical and cultural understanding, Sc. Bull. of BSU. Ser. "Phil. Soc. Law", 10 (259) (40) (Belgorod, NRU "BelSU" Publishing House "Belgorod", 2017).

8. S.I. Golod, Monogamous Family: Crisis or Evolution?, Soc.-Polit. J., 6, (1995).

9. N.L. Pushkareva, Z.Z. Mukhina, N.A. Mitsyuk, Townswomen and townsmen in the political, economic and cultural processes of Russian urbanization of the XIV-XXI centuries (XI International Scientific Conference of the Russian Association of Female History Researchers, Nizhny Novgorod, October 4-7, 2018)], Woman in Russian Society, 1, (2019).

10. M.A. Kashina, L.A. Vasilenko, The fractality of gender relations and the use of the gender resource of public policy and management in modern Russia, Woman in Russian Society, 2, (2019).

11. P.A. Sorokin, The crisis of the modern family, Bull. of Mosc. Univ. Series 18. Soc. and Polit. Science, 3, 65-79.

12. G.G. Sillaste, Social transitions and the formation of a new gender order, Woman in Russian Society, 2, 5 (2019).

13. B. Smorodin, Divertissement of feminism, Theological Leaflet, Reformation Society, $\mathbf{8}$. Information on http://baznica.info/article/divertisment-feminizma (Accessed 18 April 2019) (1999). 